\title{
Stratigraphy and textural characteristics of the 1982-83 tephra of Galunggung volcano (Indonesia): implications for volcanic hazards
}

\author{
A. Gourgaud ${ }^{\text {a }}$, J. -C. Thouret ${ }^{\mathrm{a}}$ and J. -L. Bourdier ${ }^{\mathrm{b}}$ \\ ${ }^{a}$ Université Blaise Pascal, UMR 6524, Magmas et volcans, Centre de Recherches \\ Volcanologiques, 5 rue Kessler, 63038 Clermont-Ferrand Cedex, France \\ ${ }^{\mathrm{b}}$ Université d'Orléans, UMR 6530, Centre de Recherches Volcanologiques, BP 6759, 45067 \\ Orléans Cedex 2, France
}

\section{Abstract}

The Galunggung volcano in western Java (Indonesia) was the site of historical activity in $1822,1894,1918$, and 1982-83, located in a pre-historical horseshoe-shaped caldera. In 1982-83, a nine-month-long eruption generated successively (1) ash-and-scoria flows channeled in two valleys and extending $6 \mathrm{~km}$ from the vent (vulcanian phase 1), (2) surges and ash falls related to the excavation of a wide maar crater, with ash columns $20 \mathrm{~km}$ high (phreatomagmatic phase 2), and (3) ash and scoria falls that built a small cone inside the maar crater (strombolian phase 3).

During phreatomagmatic phase 2, there was a significant increase of explosivity. Paradoxically, the magma composition had evolved from andesite to primitive magnesian basalt. Jet-plane incidents were recorded during this period: on the June 24 and July 13, 1982, two Boeing 747 aircraft experienced engine power loss when passing through the plume.

The vertical variations of grain sizes and xenolith contents of pyroclasts were measured in the 1982-83 eruptive deposits. We show that a progressive increase of the ratio of xenolith versus juvenile magma before the end of vulcanian phase 1 heralded the increase of explosivity leading towards phreatomagmatic phase 2 . In the same way, the decrease of the same ratio at the end of the phreatomagmatic phase 2 heralded the decrease of explosivity and the onset of strombolian phase 3 . The transition from phase 1 to phase 2 is also marked by a slight but continuous decrease of the vesicularity index of juvenile clasts.

We emphasize the increasing efficiency of groundwater/magma interaction during the eruption. The increasing interaction and renewed explosive activity occurred after a period of rest, during which additional groundwater was supplied in the vicinity of the magma column.

The data suggest that it would have been possible to predict as soon as April-May 1982 the transition from vulcanian to phreatomagmatic activity, and consequently the corresponding increase in explosivity.

Author Keywords: Indonesia; Galunggung volcano; stratigraphy; volcanic hazards; vulcanian; phreatomagmatism 


\section{Introduction}

Galunggung stratovolcano in western Java $\left(108^{\circ} 04^{\prime} \mathrm{E}, 7^{\circ} 15^{\prime} \mathrm{S}\right)$, about $100 \mathrm{~km}$ southeast of Bandung, is one of the many active volcanoes located along the $6000 \mathrm{~km}$-long Indonesian arc, that results from the subduction of the Indian-Australian plate beneath the Eurasian plate (Fig. 1). Indonesia contains more active and potentially active volcanoes than any other country in the world. Eighty-two have erupted, sometimes repeatedly, during historical times (Simkin and Simkin). Indonesia is also ranked fourth in world population with about 180 million inhabitants, of which $80 \%$ are gathered on the island of Java. In 1982-83, Galunggung volcano erupted and caused extensive damage but no direct casualties.

Galunggung volcano exhibits a horseshoe-shaped caldera, open to the southeast (Fig. 2), probably formed by a major collapse of the southeastern flank of the volcano, more than 25,000 years ago (Juwarna et al., 1986). Related debris-avalanche deposits cover about $175 \mathrm{~km}^{2}$ (Escher, 1925), providing the hummocky topography of the "Ten Thousands Hills" area in the vicinity of the city of Tasikmalaya.

Before 1982, Galunggung erupted in 1822, 1894 and 1918 (Kusumadinata et al., 1979). Shortlived eruptions generated pyroclastic flows and lahars in 1822 (4000 victims), followed by dome extrusion a few months later. In 1894, the eruption disrupted the 1822 dome but no pyroclastic flows were reported. In 1918, a new lava dome (Gunung Jadi) emerged from the crater lake. In 1950, a huge landslide generated lahars that caused extensive damage. In 195859 , fumarolic activity increased but without eruption.

The last eruption in 1982-83 was exceptionally long, lasting about nine months. During this eruption, the composition of the erupted magma evolved from andesite $\left(58 \% \mathrm{SiO}_{2}\right)$ to $\mathrm{Mg}$ rich basalt $\left(47 \% \mathrm{SiO}_{2}\right)$, while the style of the eruption changed drastically through time (Katili; Sudradjat and Gourgaud). Previous studies of this eruption addressed the magma genesis ( Gerbe, 1989; Gerbe and Harmon) and volcanic hazards (Gourgaud; Gerbe and Gerbe). This paper provides a more detailed report of the stratigraphy, extent and chronology of the pyroclastic sequences, with emphasis on the pyroclastic-flow and surge deposits. The paper also focuses on the changing eruptive styles during the course of the eruption, with special attention to the transition from the initial vulcanian phase to the following phreatomagmatic phase.

Vulcanian eruptions are common on andesitic and basaltic andesite volcanoes. Vulcanian explosions (Murata; Melson and Nairn) are characterized by small volumes of ejected products $\left(10^{2}-10^{6}\right.$ tons $)$ and high proportions of non-juvenile material. During active periods, time intervals between explosions may vary from minutes to days. Pyroclastic flows may occur, as at Ngauruhoe in 1975 (Self et al., 1979) and Lokon-Empung in 1991 ( Lecuyer, 1998). The involvement of groundwater is possibly significant but not essential. Alternatively, vulcanian eruptions are phreatomagmatic, as suggested by Schmincke (1977).

Phreatomagmatic style is characterized by mushroom clouds and base surges. The base-surge deposits typically exhibit dune-like features and cross-bedded layers, U-shaped channels, accretionary lapilli, vesicular tuffs, and a high content of accidental clasts (Moore; Lorenz; Lorenz; Fisher; Kienle and Self).

The observers of Volcanological Survey of Indonesia (Katili and Sudradjat, 1984) divided the 1982-83 eruption into three distinct phases. We emphasize ( Gourgaud et al., 1989 and this 
study) the increase of explosivity (as Volcanic Explosivity Index, Newhall and Self, 1982) from phase 1 to phase 2, with higher plume height, larger volume deposits and drastic changes of crater morphology. The analysis of the 1982-83 eruptive products has been previously performed ( Gourgaud et al., 1989). It has been completed for this work, with focus on the transition between phases 1 and 2 .

A pending question is thus, could have the renewal of explosive activity of phase 2 been predictable? In this study, we have examined the pyroclastic-flow, surge, and fallout deposits, the textural and componentry characteristics of the pyroclastic sequences to track systematic variations of clast vesicularity, grain size and xenolith proportions that could announce the transition from phase 1 to phase 2 in the stratigraphic record. Ultimately, our study aims to anticipate volcanic hazards.

\section{Narrative of the 1982-83 eruption}

The Galunggung volcano had been quiet for 64 years before the 1982 eruption. No significant precursor was observed during field investigations carried out 6 months prior to the eruption. The eruption started on April 5, 1982 at dawn without any identified precursory event. However, no permanent seismic equipment was installed at that time on the volcano. The population living on the slopes of the volcano fled the area and about 80,000 people were evacuated.

The eruption can be divided in three phases, on the basis of the eruptive phenomena reported by Katili and Sudradjat (1984). The summary hereafter and in Table 1 stems from investigative reports and papers from Katili and Gourgaud, and from new field data acquired in 1991-93.

The vulcanian phase 1, from April 5 to May 13, 1982, produced ash-and-scoria flows, ash falls, and lahars.

The phreatomagmatic phase 2, from May 17 to October 1982, emplaced pyroclastic flows, surges and ash falls.

The strombolian phase 3, from November 1982 to January 1983, delivered scoriaceous ashfalls and a small lava flow.

Most field observations of the eruption are summarized in Table 1.

\subsection{Vulcanian phase 1 (April 5-May 13, 1982)}

The April 5, 1982 eruption lasted only a few hours. After 3 days of relative quiescence, a strong explosion then occurred on April 8. A few houses were destroyed by ballistic blocks as far as $4 \mathrm{~km}$ away from the crater. The eruption also produced ash-and-scoria flows. Two major eruptions with pyroclastic flows also occurred on April 25 and May 6, 1982.

During phase 1, about $20 \%$ of the volume of the 1918 dome was removed. Quiet intervals between major eruptions lasted few days during phase 1 . Phase 1 was previously defined as vulcanian (Gourgaud et al., 1989) on the basis of observations of the activity carried out by 
Volcanological Survey of Indonesia (VSI), on the volumetrically dominant ash-and-scoria flow deposits ( Fig. 2), and on common bread-crust bombs in the proximal fallout deposits.

\subsection{Phreatomagmatic phase 2 (May 17-October, 1982)}

According to the observed events and relevant tephra stratigraphy, phase 2 can be divided into two phases: 2a, from May 17 to August 1982, and 2b, from September to October 1982.

Phase $2 \mathrm{~b}$ represented a progressive transition of activity towards the eruptive regime of phase 3.

\subsubsection{Phase 2a}

A major eruption occurred from the May 17-19, 1982 and blew up to $60 \%$ of the previous lava dome. A new, enlarged vent $700 \mathrm{~m}$ across was opened. Pyroclastic flows traveled down the Cibanjaran and Cikunir rivers (Fig. 2).

Other major eruptions occurred on June 3-5 and June 24-25. Ashfall deposit as much as $13 \mathrm{~cm}$ thick was deposited $6 \mathrm{~km}$ away from the vent, in Cikasasah observatory area, during June 24-25 eruption.

On the July 13, 1982, a major eruption sent up an eruptive column whose plume was drifted eastward. The eruption continued on July $14-17$. As much as $80 \%$ of the Gunung Jadi dome was removed by that time.

On July 28, a large eruption occurred continuing until August 1 . A new vent (200 m across and $100 \mathrm{~m}$ in depth) was observed inside the previous one.

Throughout August 1982, the explosive activity remained at a high level. Large eruptions occurred on August 5-7, 9-13 and 14-16. Finally, from August 26 to 31, came further large explosions which produced the last pyroclastic flow.

\subsubsection{Phase $2 b$}

According to eyewitnesses, in September incandescent ejecta covered the entire crater rim. At this time, the eruption style changed again. Medium-sized eruptions occurred on September 2-4, 15-21 and 24, 1982. Major eruptions occurred on October 8, 14, 18 and 28. Lahars swept down the Cibanjaran and Cikunir valleys (Table 1).

\subsubsection{Eruptive style of phase 2}

The eruptive style following the May 17-19 outburst was significantly different from phase 1 . Pyroclastic flows swept down the Cibanjaran and Cikunir valleys but were less extensive than those from phase 1 . The eruptive columns were higher, being as much as $10-20 \mathrm{~km}$, and caused engine trouble on jet airplanes forcing emergency landings in Jakarta.

Phase 2 was previously defined as phreatomagmatic (Gourgaud et al., 1989) based on the erupted tephra: tuff-ring of surge deposits with U-shaped channels, antidune, vesiculated tufs, and of fall deposits with accretionary lapillis, cauliflower bombs and bomb sags, xenolith-rich stratified deposits. Moreover a new crater that intersect largely the 1918 dome, was opened. It 
is interpreted as a maar crater and $80 \%$ of the 1918 dome was removed. Phreatomagmatic tephra are rich in xenolithic material and exhibits chilled juvenile magma. During phase 2, the volume of erupted tephra was higher $\left(356 \times 10^{6} \mathrm{~m}^{3}\right)$ than in phase 1 (only $12 \times 10^{6} \mathrm{~m}^{3}$ ), as well as height of plume (see Table 1). Drastic changes occur in the crater morphology with opening of a new maar crater, $700 \mathrm{~m}$ wide that cut the previous 1918 dome. Such events are related to the increase of explosivity during phase 2 and especially during phase $2 \mathrm{a}$.

Moreover, the average time interval between major eruptions increased from a few days during phase 1 to as much as three weeks during phase 2. In addition, each explosive episode lasted longer, from a few hours to several days.

In contrast, phase $2 \mathrm{~b}$ recorded a decreasing explosive activity (no more pyroclastic flows, decrease of plume height).

\subsection{Strombolian phase 3 (November 1982-January 1983)}

It consisted of medium to small explosive events on November 3-9, 17-19 and 25, 1982 (Table 1). During December and January, the explosivity and eruptive column height decreased drastically. A small scoria cone and a small lava flow were observed, inside the large maar crater formed during phase 2. Scoriaceous lapilli covered an area only $2-3 \mathrm{~km}^{2}$ around the crater. The eruption stopped on January 8, 1983.

\section{Stratigraphy of the 1982-83 erupted deposits}

The stratigraphy of the 1982-83 deposits is based on four synthetic sections (Fig. 3). The sections are located in the proximal area (Hot River, section 1; Cikunir headwaters, $0.5 \mathrm{~km}$ from the vent, section 2; Cipanas, $2 \mathrm{~km}$ from the source, section 3), and along the Cibanjaran valley ( $3 \mathrm{~km}$ from the vent) where deposits are channeled (section 4$)$. The stratigraphic units are tentatively attributed to each of the eruptive phases 1-3 as summarized in Table 1 and below.

\subsection{Phase 1 deposits}

Two units are related to phase 1. They are exposed in sections 2, 3 and 4 (Fig. 3).

\subsubsection{Unit 1}

In section 2 (Fig. 3), unit 1 is $20-30 \mathrm{~cm}$ thick, and encompasses four thin muddy layers and cross-stratified laminae, which include uncharred twigs, wood fragments, and accidental gray pumice lumps.

In section 3, unit 1 displays highly contorted beds of gray lapilli and coarse ash, inversely or normally graded, and muddy layer incorporating soil fragments. Juvenile material is lacking.

Discontinuous pinch-and-swell lenses mantling the uneven surface of the pre-1982 substratum, stripped soil debris, and broken trunk fragments suggest deposition of unit 1 by pyroclastic surges. The uncharred twigs and wood fragments, and the hydrothermally altered, muddy ash-rich deposits suggest the pyroclastic surges were wet and at a relatively low temperature upon deposition. 


\subsubsection{Unit 2}

A several meters thick pile of pyroclastic deposits is exposed in sections 2, 3 and 4 (Fig. 3).

In section 2, unit 2 exhibits ash-rich deposits, including scoriaceous clasts and lithics, and several lenticular cross-stratified ash- to lapilli-sized deposits with interspersed ashfall deposits.

In section 3, unit 2 consists successively of a lapilli-sized and scoria-rich deposit having an oxidized top, six thin layers of lithic lapilli and yellowish fine ash, a massive lapilli-sized and muddy deposit, which contains lithic blocks and scattered scoriae, and two yellowish, coarsegrained, and lithic lapilli-rich deposit.

In section 4, ash and scoria-rich deposits, several meters thick, are exposed on the banks of the Cibanjaran river. This section (right flank of the Cibanjaram river, $650 \mathrm{~m}$ in elevation) contains at least six massive beds (numbers 1-6, section 4 of Fig. 3). A debris-flow deposit separates two groups of erupted deposits. The first group, $12 \mathrm{~m}$ thick, is related to phase 1, while the second group of thinner beds, $2.5 \mathrm{~m}$ in thickness, is related to phase 2 . The basal deposit ( $3 \mathrm{~m}$ visible) in section 4 consists of lithic clasts and scoriae. A 4- to 7-m-thick coarse pyroclastic deposit consisting of black, vesicular to scoriaceous blocks with black ash overlies the basal deposit with a sharp limit. The blocks are commonly several decimeters in diameter, some as much as $1 \mathrm{~m}$ across. The cauliflower-like blocks have a bread-crust surface, with lumps and radial fractures. This massive deposit is ungraded, although lenses of oxidized, lithic blocks are present, and in places, scoriaceous blocks aggregate towards the top of the deposit. Above a sharp contact, a third, gray to black, massive deposit about $4 \mathrm{~m}$ thick is finer-grained than the underlying deposits. In places, lenses and clots countain scoriaceous blocks up to $60 \mathrm{~cm}$ across concentrated at the top or in the middle part of the deposit.

Deposits of unit 2 represent a large part of the pyroclastic deposits that were emplaced during the 1982-83 eruption. The ash-rich pyroclastic deposits contain black, scoriaceous blocks, a variable amount of lithic clasts, and black vesicular bombs. Most of the black blocks are large, dense to slightly vesicular clasts that show a scoriaceous crust, a cauliflower-like or bread-crust surface, and radial fractures. These observations are characteristic of pyroclastic ash-and-scoria flow deposits. The thin, cross-bedded ash and lapilli layers that are in places interspersed with the block-and-ash flow deposits are interpreted as pyroclastic-surge deposits.

On the basis of the position of the deposits with distance to the crater and on the distance traveled by the pyroclastic flows observed by VSI scientists, most pyroclastic flow deposits were dated. In section 4 , the three channeled, massive deposits emplaced by ash-and-scoria flows are related to the April 8, 25 and May 6, 1982 eruptions.

\subsection{Phase 2a deposits}

\subsubsection{Unit 3}

The lower parts of unit 3 at sections 2 and 3 are correlated in showing ash to lapilli-sized and cross-bedded deposit with accretionary lapilli. 
The upper massive deposits termed 4, 5, and 6 in section 4 (Fig. 3) are 50-100-cm-thick, ashrich, with a finer-grained, oxidized top. From base to top, we distinguish (1) a 50-cm-thick deposit of black ash, small scoriae, and vesicular blocks, (2) a 1-m-thick yellow-brownish, ash-rich deposit including scoriae and lithic blocks, and (3) a 50-cm-thick, brownish deposit of ash, scoriae and lithic fragments. Blocks present in these beds are decimeters in diameter. The fine-grained, oxidized top is made up of ash that probably settled from the ash cloud that accompanied the pyroclastic flows.

The three massive deposits of section 4, overlying a lahar deposit that represents a break in the 1982 sequence, are interpreted as ash-and-scoria flow deposits. In the vicinity of section 4, the level number 5 is zoned and encompasses three different lithological parts. The lower part consists of 30-cm-thick deposit, gray and rich in lithic blocks, ash and scoriaceous material. The middle part is a 70-cm thick deposit of yellowish ash, blocks, and scoriae. The upper part is yellowish, rich in blocks and scoriae, and oxidized at the top.

In section 2, unit 3 (Fig. 3) includes an ash-and-scoria flow deposit, having a variable amount of lithic fragments up to 20-25 cm across. We correlate this deposit with pyroclastic flow of section 4, both being thought to have been emplaced by the May 17-19, 1982 eruptive events.

\subsubsection{Unit 4}

The ca 3.5-m-thick section 1 (Hot River area, $890 \mathrm{~m}$ elevation, Fig. 3) is located $1.5 \mathrm{~km}$ away from the vent (Fig. 2). Three massive deposits labeled 1, 6 and 12 in section 1 ( Fig. 3), and interpreted as pyroclastic-flow deposits, are interbedded with several pyroclastic-surge and fall deposits.

The lowermost, block and ash-rich deposit includes vesicular to scoriaceous blocks and bombs up to $1 \mathrm{~m}$ in diameter. This deposit is similar to the deposit labeled 6 in section 4 (Fig. 3). Lithological analysis will confirm these field observations (see section 6.2). We interpret that this pyroclastic flow was emplaced on July 13, 1982.

Thin, stratified ash layers, collectively $40 \mathrm{~cm}$ thick (labeled 2-5 in section 1), either yellowish and fine-grained or grayish-brown and coarse-grained, display laminae and low-angle crossstratification. They point to ashfall and pyroclastic-surge deposits.

A 1-m-thick, black, massive deposit, labeled 6 in section 1, is considered as being an ash-rich pyroclastic-flow deposit including scoriae, bombs, and lithic fragments. We attribute this pyroclastic flow deposit to the July 28, 1982 eruption.

Thin tephra-fall deposits (labeled 7, 8, 9 in section 1), composed of lapilli, fine ash and accretionary lapilli, are overlain by a debris flow deposit (labeled 10 in section 4). The overlying 32-cm-thick deposit consists of four cross-bedded layers (labeled 11) of lapilli grading into coarse and fine ash. These deposits form dunes mantling the eastern flank between 850 and $950 \mathrm{~m}$ in elevation. They record a series of short-lived, repeated explosive events that produced pyroclastic surges during phase $2 \mathrm{a}$.

A third ash-and scoria pyroclastic-flow, labeled 12 in section 1, is related to one of the August 1982 eruptions. 
The deposits of units 3 and 4 of are rich in accidental clasts and display some features of base surges, such as asymetrical dunes, accretionary lapilli, and cross-bedded and muddy beds. The channeled ash-and-scoria flow deposits are also richer in xenoliths, as 1918 dome fragments, than those related to phase 1 . These deposits are interpreted to be phreatomagmatic in origin (Gourgaud et al., 1989) and are attributed collectively to phase 2a.

\subsection{Phases $2 b$ and 3 deposits (unit 5 )}

Unit 5 consists of the late-erupted tephra-fall deposits in the proximal area. In section 2 (Fig. 3 ), numerous stratified layers of black tephra-fall deposits are exposed. Fine-grained, lapilli or ash-rich layers alternate with coarse-grained beds, which include black scoriaceous fragments and varying unvesicular lapilli and blocks.

In section 3 (Fig. 3), ten thin, fine-grained layers are exposed. At the base of the sequence, a normally graded bed of accretionary lapilli displays laminae, and low-angle cross-stratified layers. The rest of the sequence encompasses several yellowish, fine-grained layers of compact muddy ash that contrast with gray to black, coarse-grained layers of dense, juvenile lapilli.

In the Cibanjaran valley (section 4, Fig. 3), the whole section is overlain by several layers of lapilli-fall deposits and cross-bedded pyroclastic-surge deposits. These deposits are related to units 4 or 5 .

At Hot River, unit 5 of section 1 (Fig. 3) consists of tephra-fall deposits. The stratified layers of ash and lapilli-fall deposits increase rapidly from 1.5 to $8.5 \mathrm{~m}$ in thickness on the rims of the 1982 crater.

At Cikunir (section 2, Fig. 3), thin layers of vesicular lapilli with a large amount of coarse ash alternate with layers rich in dense lapilli (mostly juvenile with some accessory lithics), scoriae, and small bombs. These tephra-fall deposits are interpreted as strombolian ejecta.

The deposit of Cipanas (section 3, Fig. 3) displays thin yellowish muddy layers of ash with accretionary lapilli that point to some phreatomagmatic explosive activity. In contrast, wellstratified layers of black, coarse juvenile lapilli, either scoriaceous to vesicular or dense (basaltic in composition), are evidence for strombolian airfall deposits. Overall, amounts of scoriaceous strombolian lapilli increase from base to top of the unit 5 deposits.

\subsection{Interpretation of the $1982-83$ erupted tephra}

Three main sequences of erupted tephra are related to three distinct eruptive phases:

(1) A series of initial, high-energy pyroclastic-surges occurred at the onset of the eruption. They were followed by, and interspersed with a series of lithic-rich pyroclastic flows. Then, the activity changed to produce scoriaceous block-and-ash flows. A series of large-scale pyroclastic flows traveled as far as $2-6 \mathrm{~km}$ in the valley channels. A few brief pulses of pyroclastic surges were interspersed with the short-lasting and small-volume tephra fallout. This sequence is related to the vulcanian phase 1.

(2) A major break in the eruptive activity is confirmed by interbedded, thin debris-flow deposits. Following this break, several pulses of energetic base surges emplaced the dune-like, 
cross-bedded deposits on the crater slopes, suggesting a sudden increase in magma-water interactions (phase 2). At this time, repeated tephra-fall deposits of small volume became predominant. A few lithic-rich pyroclastic flows were emplaced during phase $2 \mathrm{a}$. At the end of phase 2 (phase $2 b$ ), the phreatomagmatic airfall deposits denoted the transition to the late strombolian activity.

(3) The activity clearly shifted to the long-lasting, strombolian phase 3 that emplaced a thick pile of lapilli and ashfall deposits.

In 1982, the tephra-fall deposits (thickness $<5 \mathrm{~cm}$ ) mantles a large area, covering some $600 \mathrm{~km}^{2}$ (Katili and Sudradjat, 1984). Based on our stratigraphical study, sampling of pyroclastic-flow, surge and air-fall deposits has been performed aiming at analyzing grainsize and componentry. The following analysis focuses on the transition between phases 1 and 2 .

\section{Volume, distribution and composition of tephra}

\subsection{Volume and distribution of tephra}

Pyroclastic deposits are now exposed inside the U-shaped caldera. The pyroclastic-flow deposits are exposed along the banks of the Cikunir and Cibanjaran valleys (Fig. 2). The total volume of the pyroclastic-flow, surge and tephra-fall deposits of the 1982-83 eruption was estimated to be about $0.37 \mathrm{~km}^{3}$ (Katili and Sudradjat, 1984). As little as $0.014 \mathrm{~km}^{3}$ was still preserved in 1989 inside the caldera (Gourgaud et al., 1989).

During phase 1, pyroclastic flows and ash falls were produced. The pyroclastic flows were predominant in volume and decreased during phase 2 . The volume of pyroclastic-flow deposits and related ashfall and surge deposits is estimated to be about $0.012 \mathrm{~km}^{3}$ (Table 1).

Phase 2 was characterized by strong phreatomagmatic explosions (Gourgaud et al., 1989) producing most ash falls and surges. However, pyroclastic flows also occurred. The estimated volume of the deposits was $0.356 \mathrm{~km}^{3}$.

Phase 3 was mainly strombolian and corresponded to a drastic decrease in the explosive activity. The estimated volume of strombolian products was only about $0.003 \mathrm{~km}^{3}$.

\subsection{Characteristics and chronology of pyroclastic flows}

For sedimentological analysis, we sampled deposits that represent the transition between phases 1 and 2. Most of the samples were collected in the Cibanjaran channel or in the vicinity of the crater area (Fig. 2). In the Cibanjaran valley, 2-3 km away from the vent, five pyroclastic flow units can be observed, totaling $10 \mathrm{~m}$ in thickness. According to eye-witnesses (Katili and Sudradjat, 1984), these deposits were emplaced on April 8, 25, May 6 (phase 1), and May 17-19 and July 13 (phase 2). Two additional scoria-rich flows occurred on July 28 and August 1982. 


\subsection{Compositional features}

The mineralogical and geochemical evolution of the erupted tephra through the 1982-83 Galunggung eruption (Gerbe, 1989; Gerbe and Harmon) indicates that the magma composition evolved from andesite $\left(58 \mathrm{wt} \% \mathrm{SiO}_{2}, 3 \% \mathrm{MgO}\right)$ to high-Mg basalt ( $47 \mathrm{wt} \%$ $\left.\mathrm{SiO}_{2}, 12 \% \mathrm{MgO}\right)$. The mineralogical changes through time are summarized in Table 1.

\section{Grain-size analysis}

Samples were collected in almost each unit of the three stratigraphic sections (sections 1, 3, 4, Fig. 2 and Fig. 3), testing for grain-size variations through time. We focus here on pyroclasticflow and surge deposits ( Fig. 4), related to phases 1 and 2a, but all data are available on request. The coarser fractions $(64-4 \mathrm{~mm})$ of samples were sieved on site by hand at half $\varnothing$ intervals. A split sample of the finer fraction (4 to $1 / 32 \mathrm{~mm}$ ) was then sieved in the laboratory.

The pyroclastic-flow deposits in the Cibanjaran valley (Fig. 3, section 4) show a complex distribution for grain size $<128 \mathrm{~mm}$ (Fig. 4a-e). Commonly, two distinct modes appear: a coarse one from 16 to $64 \mathrm{~mm}$ and a fine one from 0.63 to $0.3 \mathrm{~mm}$ whereas a minimum exists between 2 and $4 \mathrm{~mm}$. The pyroclastic-flow deposits of Cibanjaran are fine-poor, having a fine ash $(<1 / 16 \mathrm{~mm})$ content $<1.5 \%$ in all samples.

The Hot River sequence (section 1, Fig. 3) shows pyroclastic-flow, surge and ashfall deposits. Nineteen samples were collected and sieved. The grain size distribution of three pyroclastic flows observed in the field (pf. 1, 6 and 12, Fig. $4 \mathrm{f}-\mathrm{h}$ ), is complex, bi- or trimodal and similar to that of the Cibanjaran valley ( Fig. 4). The deposits of the three pyroclastic flows are finepoor, having a fine ash $(<1 / 16 \mathrm{~mm})$ content $<4 \%$. The grain-size distribution of the pyroclastic-surge deposits is generally bimodal (Fig. 4i,j). We emphasize that coarse fraction is lacking in surge deposits. The fine ash content (4-9\%) is higher than that of pyroclasticflow deposits.

The Cipanas sequence also comprises pyroclastic-flow deposits as pf4 and pf6 in section 3, surge and fall deposits. The grain-size distribution is similar to that of the deposits in previous sections, i.e. polymodal for the pyroclastic-flow deposits, and bimodal for the pyroclasticsurge deposit. All the deposits are poor in fine ash $(<1 / 16 \mathrm{~mm}$ fraction $<4 \%)$.

The grain size analysis does not reflect the transition between deposits from phase 1 and phase $2 \mathrm{a}$ (pyroclastic and surge deposits). Using coarse fractions (up to $64 \mathrm{~mm}$ ), we emphasize the complex bi- or trimodal grain-size distribution of ash-and-scoria flows.

\section{Componentry}

\subsection{Analytical procedure}

\subsubsection{Particle analysis}

Particles of the 2.8- and $4 \mathrm{~mm}$-size classes were hand-picked under a binocular stereoscope. The different components were weighed and the weight percentage was calculated. The components are juvenile scoriaceous grains, unvesicular juvenile clasts, free crystals (pyroxene, plagioclase, olivine), and oxidized xenoliths (colored 1918 dome fragments, old 
and altered lavas). Results are similar on the two rested fractions but only results from $2.8 \mathrm{~mm}$ fraction are proposed.

Measurements were carried out on unvesicular clasts to evaluate the DRE (dense rock equivalent) density, as well as on vesiculated clasts.

\subsubsection{Measurements of clast density and of vesicularity Index}

The density of juvenile fragments was measured with a pycnometer after coating fragments with a thin impermeable film. About 10 measurements per sample were carried out in the 4and 8 -mm grain classes. The mean values were then considered.

The vesicularity index (V\%) was calculated using the method of Houghton and Wilson (1989):

$$
V(\%)=100(\text { DREdensity-clastdensity }) / \text { DREdensity }
$$

The DRE density has been determined on non-vesicular, dense grains, while the average clast density is that of the most vesiculated fragments.

\subsection{Vertical variations in pyroclast lithology}

\subsubsection{The Cibanjaran pyroclastic-flow deposits (section 4)}

In the Cibanjaran valley, five pyroclastic-flow units were sampled for component analysis. In each flow unit, one, two or three beds were observed in the field and sampled (Fig. 4). The trend of the xenolithic content through stratigraphy and time is shown in Fig. 5.

The DRE density has been determined on non-vesicular, dense grains, while the average clast density is that of the most vesiculated fragments.

\subsection{Vertical variations in pyroclast lithology}

\subsubsection{The Cibanjaran pyroclastic-flow deposits (section 4)}

In the Cibanjaran valley, five pyroclastic-flow units were sampled for component analysis. In each flow unit, one, two or three beds were observed in the field and sampled (Fig. 4). The trend of the xenolithic content through stratigraphy and time is shown in Fig. 5.

The April 8 pyroclastic-flow deposit (sample pfl $>1 \mathrm{~m}$ thick and 3-4 km long), is composed of gray scoriaceous lapilli, gray, unvesicular, oxidized lapilli and free crystals as juvenile components. The two types of lapilli are quite similar in containing plagioclase and pyroxene phenocrysts. The xenolith component is abundant (22\%) and composed of angular, rounded and elongated lapilli, which are very oxidized.

The April 25 pyroclastic-flow deposit (pf 2 and 2', $2.5 \mathrm{~km}$ long, 5-7 m thick) is composed of dark gray (pf 2) to gray yellow ( $\mathrm{pf} 2^{\prime}$ ) scoriaceous lapilli, rounded gray (pf 2) to yellow gray 
(pf 2'), lithic lapilli, crystals (plagioclase), and fragments of cumulate aggregates (plagioclase, pyroxene, olivine). The juvenile lapilli comprise plagioclase phenocrysts. The xenolith component (19-21\%) is slightly less abundant than that of the April 8 pyroclastic flow.

The May 6 pyroclastic-flow deposit (pf $3 \mathrm{a}$ and 3b, $6 \mathrm{~m}$ thick and $6 \mathrm{~km}$ long) is composed of gray (pf. 3a) to grayish yellow (pf 3b), juvenile lapilli (predominant scoriaceous grains and minor lithics), crystals (plagioclase, pyroxene), and oxidized xenoliths. The percentage of the xenolith component increases significantly from 22 to $28 \%$.

The May 17-19 pyroclastic-flow deposit (pf $5 \mathrm{a}, \mathrm{b}, \mathrm{c}$ ) is composed of yellowish scoriaceous lapilli, yellow and red, oxidized and angular, unvesicular lapilli and crystals (plagioclase, pyroxene). Some juvenile lapilli show a typical cauliflower shape. We emphasize that the xenolith component increases again from 28 to $35 \%$.

The July 13 pyroclastic-flow deposit (sample pf. 6) is composed of dark gray, scoriaceous and unvesicular lapilli, with plagioclase, pyroxene and olivine phenocrysts, and free crystals (plagioclase, pyroxene). The xenolith component (17\%) is a dark gray almost aphyric lava.

\subsubsection{Pyroclastic-flow, surge and ashfall deposits in Hot River area (section}

\section{1)}

In the proximal area, a complete section was sampled, that includes pyroclastic-flow, surge and airfall deposits. Nineteen beds (or groups of beds) were observed and fourteen were sampled for the purpose of comparing the componentry (Fig. 3, section 1). The evolution of the xenolith content through time is shown in Fig. 6.

The scoria-flow deposits in the lower part of the section 1 (pf 1), are composed of dark, scoriaceous and unvesicular lapilli. The xenolith content (14\%) and the textures of juvenile and xenolith components are similar to that of the pf. 6 sample of the Cibanjaran valley (section 4, Fig. 3). We consider that this deposit was delivered by the July 13 eruption.

The following sequence is composed of four units of ashfall and pyroclastic-surge deposits (numbers $2-5$ in section 1 ). The juvenile and xenolith lapilli are generally oxidized (gray to yellowish). The xenolith content increases to as much as $56 \%$.

The block-and-ash and scoria-rich pyroclastic-flow deposit (pf 6) is related to the July 28 eruption. Scoriaceous lapilli are dominant and black in color. The xenolith content (17-27\%) increases compared to that of the July 13, 1982 pyroclastic flow deposit.

Sequence 7-11 of section 1 (Fig. 3) is composed of ashfall, pyroclastic-surge and debris-flow deposits. Only three units were analyzed. The lapilli are gray to yellowish, with a xenolith content as high as $42-66 \%$.

The pf 12 pyroclastic-flow deposit, ash-and scoria-rich, is attributed to one of the August 1982 eruptions. Juvenile and xenolith lapilli are gray to yellowish. The xenolith percentage (25-33\%) increases slightly compared to that of the July 28 pyroclastic flow deposit. No pyroclastic flow was observed in the Cibanjaran river following August 1982. 
The last sequence (af. 13-19, $1 \mathrm{~m}$ thick) of section 1 is composed of ashfall deposits. The four layers analyzed are characterized by a gray to yellowish color and a high xenolith content $(35-52 \%)$.

\subsection{Changes in density and vesicularity}

Density measurements have been performed on pyroclastic-flow samples from the Cibanjaran sections (Fig. 3). The density of the unvesicular component evolved slightly from 2.37 to 2.45. The density of the vesiculated clasts evolved from 1.31 to 1.50 ( Fig. 7).

The vesicularity index within deposits of the Cibanjaran section evolved through time from 46 to 39 (Fig. 7). According to the classification of Houghton and Wilson (1989), the corresponding clasts are moderately vesiculated.

The evolution through time of the density of vesiculated clasts and of the vesicularity index is significant (Fig. 7). The density of vesiculated clasts increased from 1.31 to 1.50. Except for the first pyroclastic flow event (April 8), there is a slight but continuous increase in density through time, from April 25 to May 17-19. Likewise, the vesicularity index continuously decreases from 46\% (April 25) to 39\% (17-19 May). The highest vesicularity index corresponds to the April 25 eruption, when the xenolith content and the clast density of the deposit were at their lowest (about 20\% and 1.31, respectively). In contrast, the lower vesicularity index corresponds to the deposits of the May 17-19 phreatomagmatic explosions, when the vesiculated fraction of pyroclastic flows showed the highest densities (1.46-1.50) and the highest xenolith content (about 35\%).

The progressive decrease in the vesicularity index during the course of the eruption is attributed to a magma-water interaction. We suggest that the magma-water interaction increased during the transition from phase 1 to phase 2. The gradual decrease in the degree of vesiculation continued while the phreatomagmatic character of the eruption was increasing. Such evolution is visible through the whole succession of pyroclastic-flow deposits.

\section{Discussion: volcanic hazards and eruption dynamics}

During phase 2, the explosivity increased considerably, while paradoxically the magma composition evolved from andesite to primitive basalt. A maar $700 \mathrm{~m}$ across was formed. This evolution is partly related to an increase in the groundwater/magma ratio during the eruption (Gourgaud et al., 1989). A change in the rheological properties of the magma would have been important, as a hot and low viscosity basaltic melt would have favored a more efficient magma-water interaction.

The observed phreatomagmatic tephra are related to the opening of the maar crater, which truncated the preexisting 1918 dome. The tephra are mainly composed of pyroclastic-surge deposits and ash-fall beds. The yellow-gray to ochre color of the deposits is caused by the abundance of xenolithic material, i.e. fumarolized and oxidized fragments. Phase 2 is characterized by a xenolith content much higher than in phase 1. A muddy deposit that coated the inner walls of the caldera for two years after the end of the eruption, indicates that water was involved. The temperature of the deposit, inferred from infrared spectrometry on uncharred wood samples, was about $175^{\circ} \mathrm{C}$ only (Gourgaud et al., 1989). The vegetation on the southern slopes of the pre-existing dome was not charred, also demonstrating a low temperature. In 1984, we observed uncharred trees cut at half height and debarked on the blast 
side. All these data are consistent with the emplacement of wet base surge during phase 2 . As proposed by Gourgaud et al. (1989), the magma supply was significantly higher during phase 2 ( Table 1).

We show that the vulcanian phase 1 included pyroclastic flows with a high xenolithic content (18-28\%). Moreover, at the end of phase 1, the May 6 deposits recorded an increase in the xenolith content that heralded the phreatomagmatic paroxysm of May 17-19. During the course of phase 2, the xenolith content of pyroclastic-flow deposits first decreased, increasing again after the eruption of July 13, anticipating the opening of the second maar.

Such results would have permitted the anticipation of volcanic hazards and jet plane incidents, if componentry and textural analysis had been performed during the course of the eruption. We emphasize that sedimentological analysis could be performed during long-lasting eruptions, as Galunggung in 1982-83. The fluctuations of the xenolithic content, for example, was easy to evaluate during the course of the 1982 eruption and would have enabled the prediction of some important changes in the eruptive style.

As well as xenolith variations, the changes in vesicularity of scoriaceous lapilli from the pyroclastic-flow deposits also recorded an increase in magma-water interaction.

The high xenolith content of the pyroclastic-flow deposits during phase 1 allows us to reinterpret the evolution of eruptive styles. As previously proposed by Schmincke (1977), the vulcanian eruption style may resemble to the phreatomagmatic style. So, according to Schmincke proposal, the dynamism of phase 1 was already phreatomagmatic and phase 2 recorded furthermore the increase in phreatomagmatic activity.

\section{Conclusion}

During phase 2 of the 1982-83 eruption, the explosivity increased considerably with concomitant jet plane incidents. This drastic change in the style of the eruption is explained by an increase in the efficiency of groundwater-magma interaction. A counting of the xenolithic and juvenile grains in the erupted sequence of tephra shows that the increase of the ratio of xenolith/juvenile magma heralded the phreatomagmatic paroxysm. Such an estimation may be carried out on ashfall deposits during the course of an eruption and may be used to anticipate volcanic hazards, i.e. an increase in explosive activity that eventually leads to high columns and potential threats to the safety of aviation.

Considering the historical activity and the 1982-83 eruption, three main eruptive phenomena could occur in the area, in case of a future eruption of Galunggung volcano. Firstly, pyroclastic flows would be channeled down the two principal valleys as far as $6 \mathrm{~km}$ downvalley, threatening villages. The flows would probably transform downstream into lahars. Secondly, pyroclastic surges generated during phreatomagmatic events would be responsible for great damage as far as $5 \mathrm{~km}$ from the vent. Thirdly, ash falls would represent a nuisance for both agriculture and health. 


\section{Acknowledgements}

The authors are grateful to the French Foreign Office for promoting a cooperation in volcanology between France and Indonesia. The Centre de Recherches Volcanologiques supported this work. The Volcanological Survey of Indonesia is thanked for its logistical help. G. Boudon is thanked for help in the field. D. Palladino, G. Valentine and an anonymous reviewer are thanked for constructive suggestions to improve the paper and V. O'Dwyer for help in improving the English of the manuscript. N. Thomas is thanked for help in density measurements

\section{References}

Escher, B.G., 1925. L'éboulement préhistorique de Tasikmalaya et le volcan Galunggung. Leidsche Geol. Mededeelingen 1, pp. 8-21.

Fisher, R.V., 1977. Erosion by volcanic base surge density currents: U-shaped channels. Geol. Soc. Am. Bull. 88, pp. 1287-1297.

Gerbe, M.C., 1989. Evolution d'une chambre magmatique zonée en système clos: exemple de l'éruption de 1982-83 du Galunggung (Java, Indonésie). Thèse Doct., Université. Blaise Pascal, Clermont-Fd II, 301 pp.

Gerbe, M.C., Gourgaud, A., Boudal, C. and Pratomo, I., 1988. Téphrostratigraphie de l'éruption de 1982-83 du Galunggung (Java, Indonésie). C. R. Acad. Sci. Paris, sér. II 307, pp. 89-94.

Gerbe, M.C., Morel, J.M. and Gourgaud, A., 1990. Evaluation des risques volcaniques au Galunggung (Java, Indonésie): apports de l'éruption de 1982-83. C. R. Acad. Sci. Paris, sér. II 311, pp. 873-878.

Gerbe, M.C., Gourgaud, A., Sigmarson, O., Harmon, R.S., Joron, J.L. and Provost, A., 1992. Mineralogical and geochemical evolution of the 1982-83 Galunggung eruption, Indonesia. Bull. Volcanol. 54, pp. 284-298

Gourgaud, A., Tjetjep, W., Ramli, L., Sudradjat, A., Vincent, P.M. and Camus, G., 1985. Risques volcaniques et circulation aéronautique: causes de perturbations provoquées par l'éruption de - du Galunggung (Java, Indonésie). C. R. Acad. Sci. Paris, sér. II 301 5, pp. $351-353$.

Gourgaud, A., Camus, G., Gerbe, M.C., Morel, J.M., Sudradjat, A. and Vincent, P.M., 1989. 1982-83 eruption of Galunggung (Indonesia): a case study of volcanic hazards with particular relevance to air navigation. In: Latter, J.H., Editor, , 1989. IAVCEI Proceedings in Volcanology 1. Volcanic Hazards, Springer, Berlin, pp. 151-162.

Harmon, R.S. and Gerbe, M.C., 1992. Oxygen isotope geochemistry of the 1982-83 eruption at Galunggung volcano, Java (Indonesia). J. Petrol. 33, pp. 585-609.

Houghton, B.F. and Wilson, C.J.N., 1989. A vesicularity index for pyroclastic deposits. Bull. Volcanol. 51, pp. 451-462. 
Juwarna, H., Wirakusumah, A.D., Soetoyo, D., Bronto S., 1986. Geological map of Galunggung volcano, West-Java. Volc. Surv. Indonesia.

Katili, J.A. and Sudradjat, A., 1984. Galunggung: the 1982-83 Eruption, VSI, Bandung 102 pp.

Kienle, J., Kyle, P.R., Self, S., Motyka, J. and Lorenz, V., 1980. Ukinrek maars, Alaska. 1. April 1977 eruption sequence, petrology and tectonic setting. J. Volcanol. Geotherm. Res. 7, pp. 11-37.

Kusumadinata, K., Hadian, R., Hamidi, S. and Reksowirogo, L.D., 1979. Data dasar Gunung api Indonesia. Catalogue of references on Indonesian Volcanoes with Eruptions in Historical Time, VSI, Bandung 820 pp.

Lecuyer, F., 1998. Relations entre le volcanisme actif et la tectonique actuelle dans la région de Tondano au nord de Sulawesi (Indonésie). Thèse Doct., Université Blaise Pascal ClermontFerrand, 163 pp.

Lorenz, V., 1973. On the formation of maars. Bull. Volcanol. 37, pp. 183-204.

Lorenz, V., 1974. Vesiculated tuffs and associated features. Sedimentology 21, pp. 273-291.

Melson, W.G. and Saenz, R., 1973. Volume, energy and cyclicity of eruptions of Arenal volcano, Costa Rica. Bull. Volcanol. 37, pp. 416-437.

Moore, J.G., Nakamura, K. and Alcazar, A., 1966. The eruption of Taal volcano. Science 151, pp. 955-960.

Murata, K.J., Donoli, C. and Saenz, R., 1966. The 1963-65 eruption of razu volcano, Costa Rica. Bull. Volcanol. 29, pp. 765-796.

Nairn, I.A. and Self, S., 1978. Explosive eruptions and pyroclastic avalanches from Ngauruhoe in February. J. Volcanol. Geotherm. Res. 3, pp. 39-60.

Newhall, C.G. and Self, S., 1982. The Volcanic Explosivity Index (VEI): an estimate of explosive magnitude for historical volcanism. J. Geophys. Res. 87, pp. 1231-1238.

Schmincke, H.U., 1977. Phreatomagmatische phasen in quartären vulkanen der Osteifel. Geol. Jb. A 39, pp. 3-45.

Self, S., Wilson, L. and Nairn, I.A., 1979. Vulcanian eruption mechanisms. Nature 277, pp. $440-443$.

Self, S., Kienle, J. and Huot, J.P., 1980. Ukinrek maars, Alaska. II. Deposits and formation of the craters. J. Volcanol. Geotherm. Res. 7, pp. 39-65.

Simkin, T. and Siebert, L., 1994. Volcanoes of the World, Geoscience Press, Tucson, AZ 349 pp. 
Simkin, T., Siebert, L., McClelland, L., Bridge, D., Newhall, C. and Latter, J.H., 1981. Volcanoes of the World, Smithsonian Institution, Hutchinson, Ross Publish. Company, Stroudsburg, PA 233 pp.

Sudradjat, A. and Tilling, R., 1984. Volcanic hazards in Indonesia: the 1982-83 eruption of Galunggung. Episodes 7, pp. 13-19 


\section{Figures}

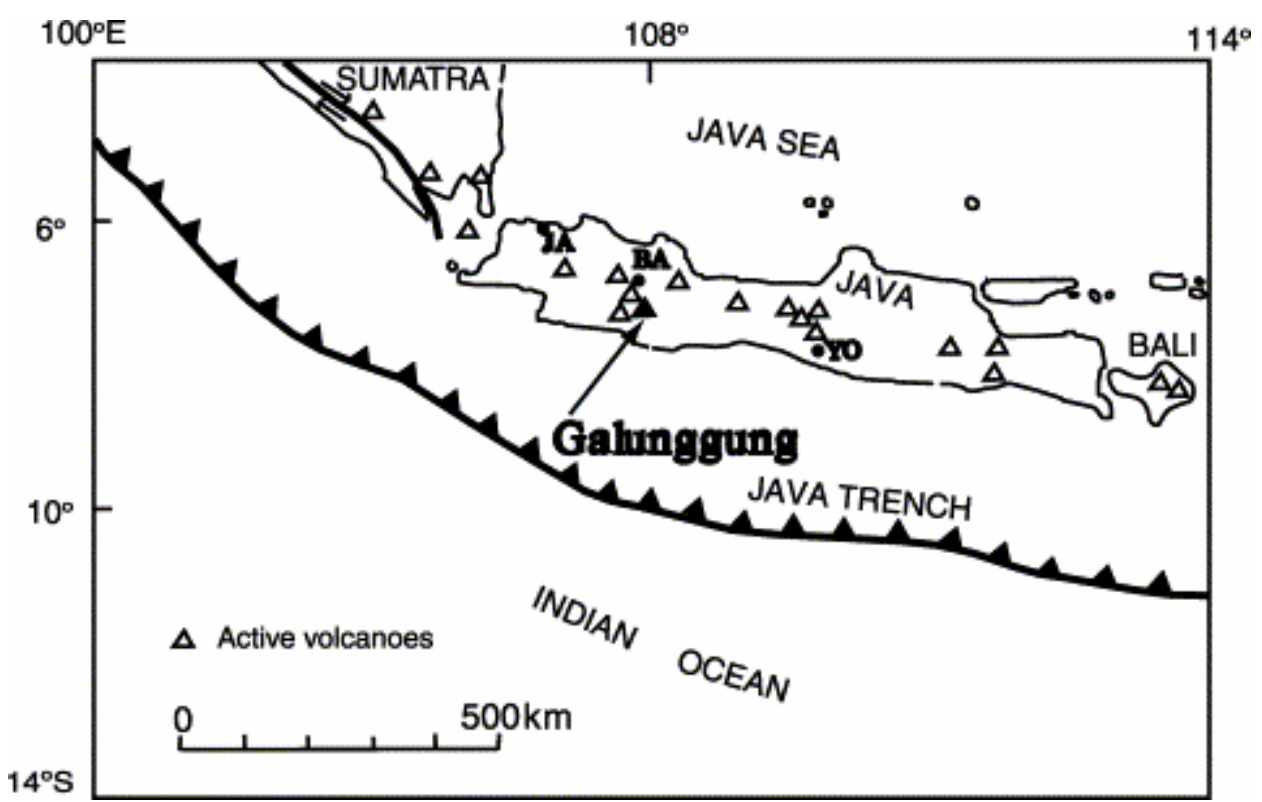

Fig. 1. Location of Galunggung volcano in Java (Indonesia), with respect to the Java trench (JA: Jakarta, BA: Bandung, YO: Yogyakarta). 


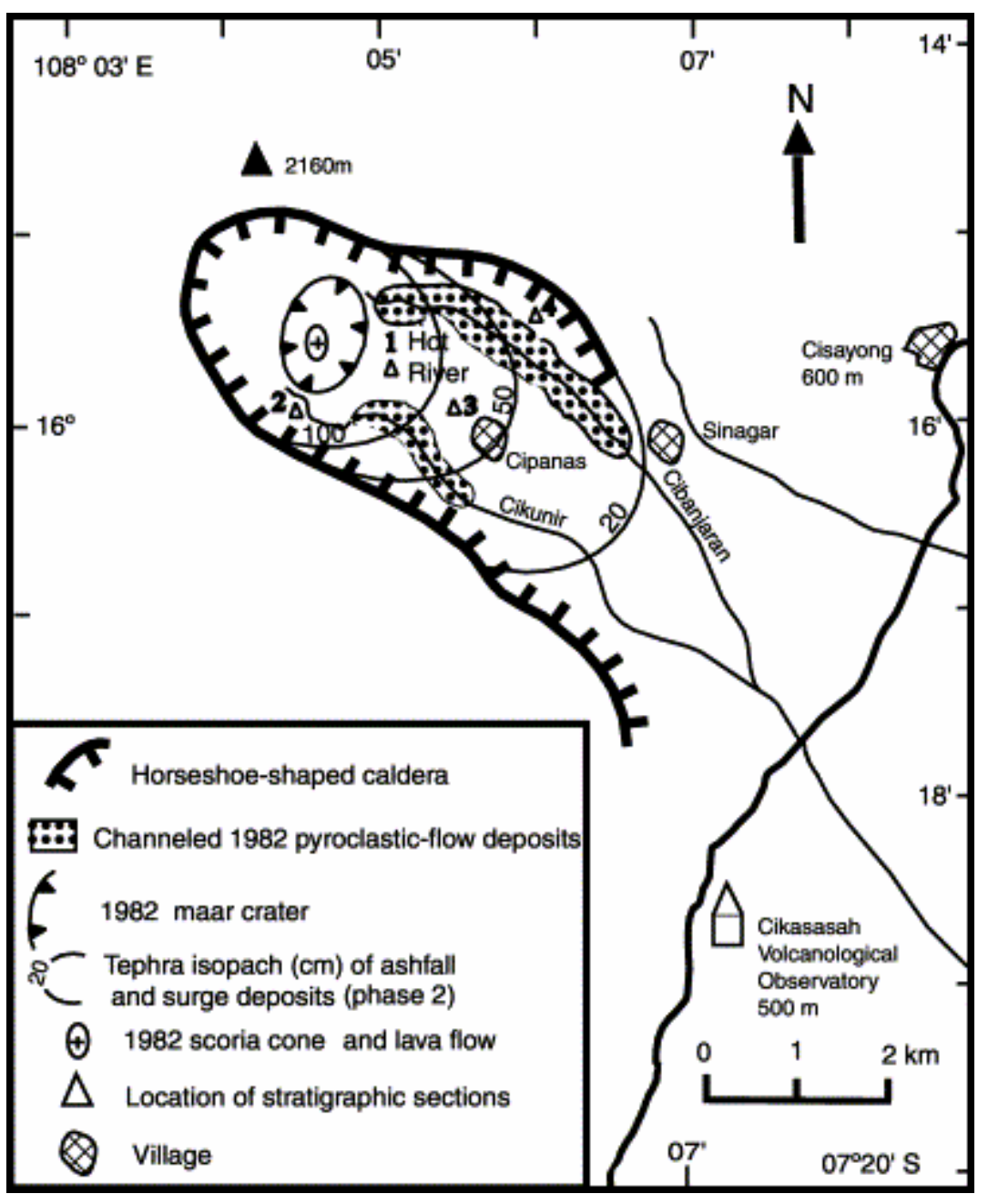

Fig. 2. Sketch map of the Galunggung horseshoe-shaped caldera and location (numbers 1-4) of selected measured stratigraphic sections. Inside the caldera, the 1982 maar crater $(1200 \mathrm{~m}$ elevation) and the 1982 channeled pyroclastic-flow deposits are shown. 


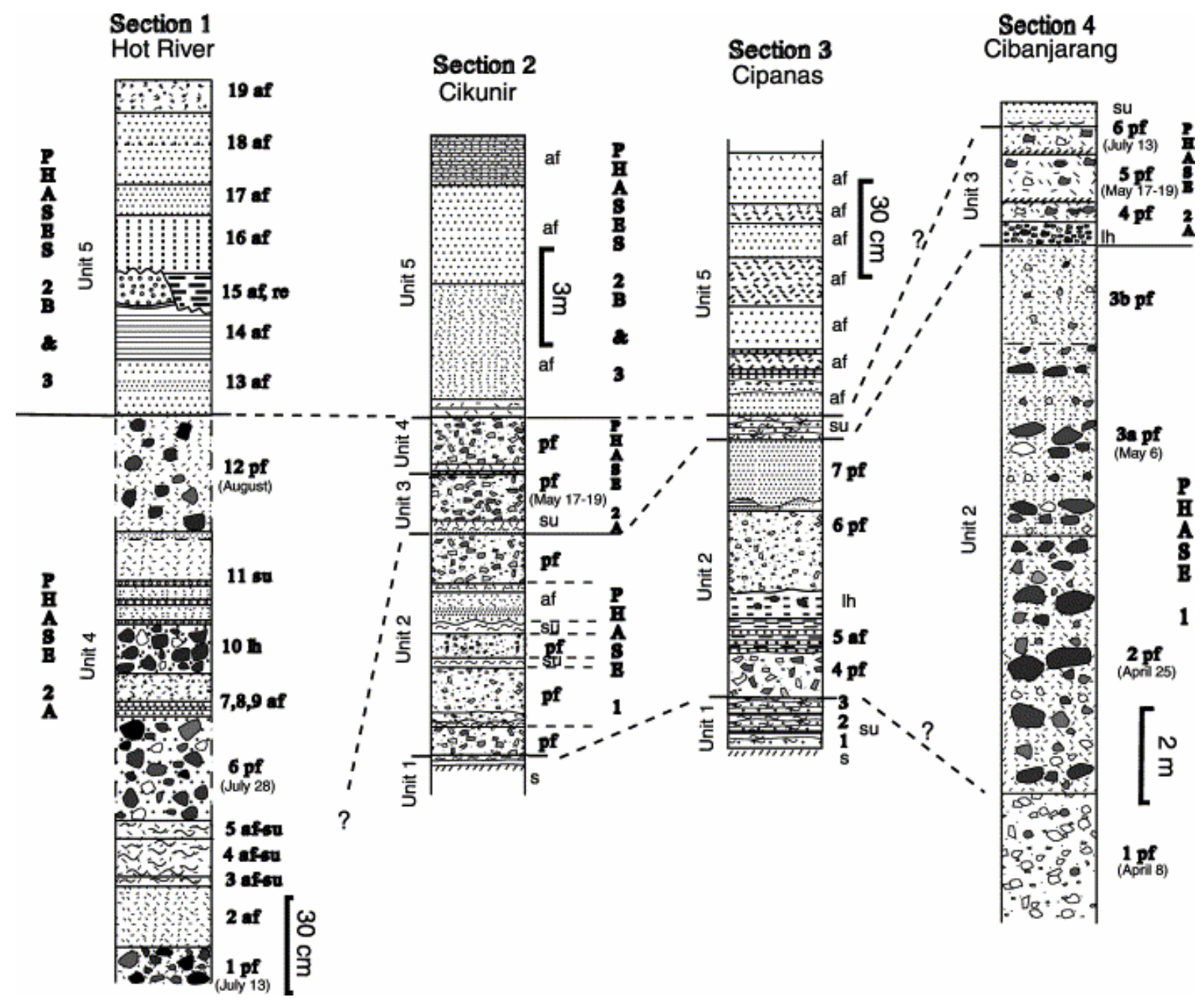

Fig. 3. Stratigraphic sections of the 1982 erupted deposits. Section 1: Hot River area on the east flank crater. Numbers 1-19 correspond with sample sites. Letter meanings: AF=ashfall deposit, $\mathrm{PF}=$ pyroclastic-flow deposit, $\mathrm{SU}=$ pyroclastic-surge deposit, $\mathrm{S}=$ soil (pre-1982 eruption surface), $\mathrm{LH}=$ lahar or debris-flow deposit, $\mathrm{RW}=$ reworked deposits. Section 2: Cikunir river nearby the maar crater (1210 $\mathrm{m}$ in elevation). Section 3 Cipanas village $(750 \mathrm{~m}$ in elevation). Numbers 1-7 in section 3 stand for sample sites. Section 4 channeled pyroclastic flow deposits in the Cibanjaran valley. Numbers 1-6 denote sample sites. 

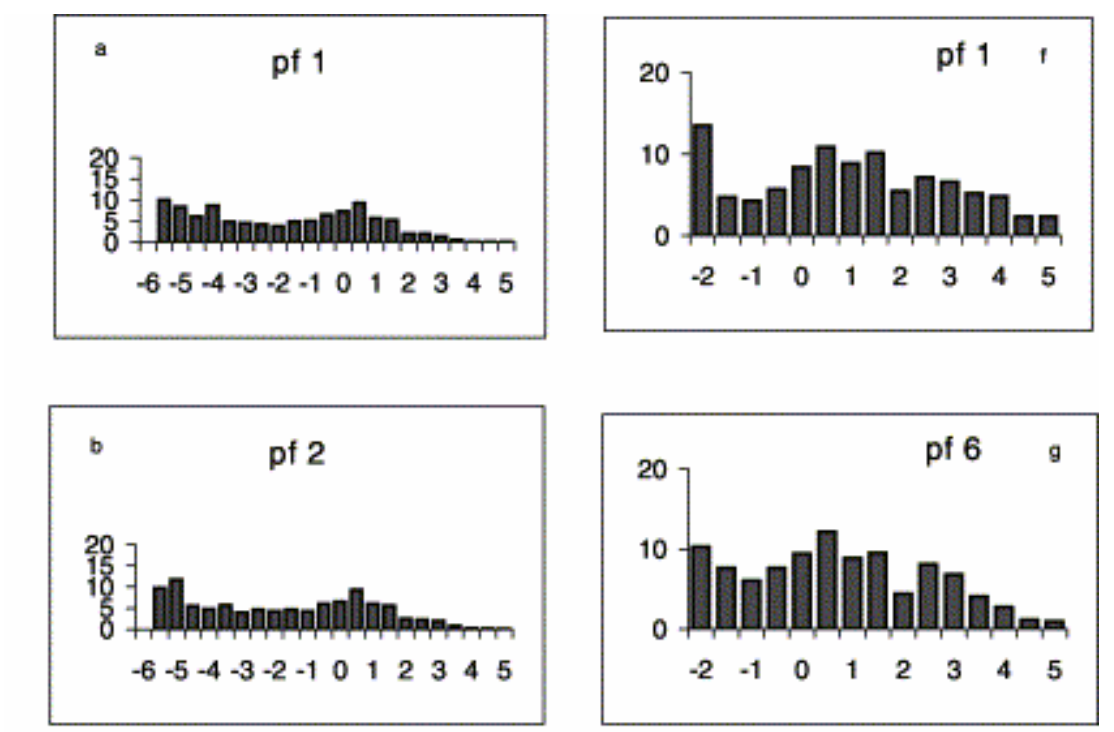

$\frac{2}{3}$


\section{Grain size (Ø)}

Fig. 4. Grain-size ( ) distribution of the pyroclastic-flow (pf) and surge (su) deposits in the Cibanjaran valley (pf1-6, a-e) and in the Hot River area (Pf 1, 6 and 12, f, g, h and su 5 and $11, \mathrm{i}, \mathrm{j})$. wt $\%$ : weight percent. 


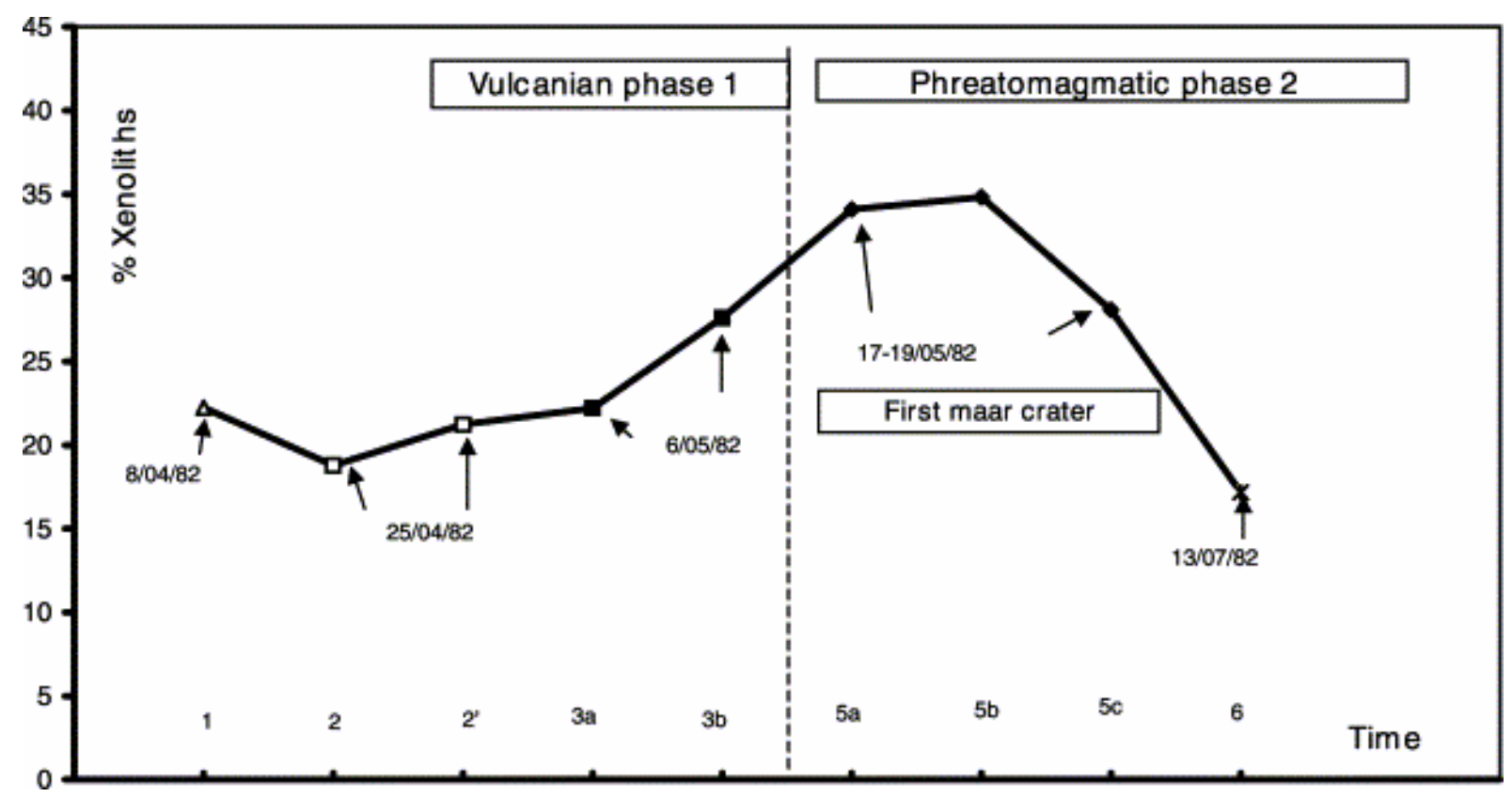

Fig. 5. Variation of the xenolith content in the size class $2.8-4 \mathrm{~mm}$ through time in pyroclastic flow deposits from the Cibanjaran valley. Numbers 1-6 indicate sample sites (section 4 of Fig. 3) in stratigraphic order. Dates (as 8/04/82) refers to the main eruptive events described in Table 1 and in text.

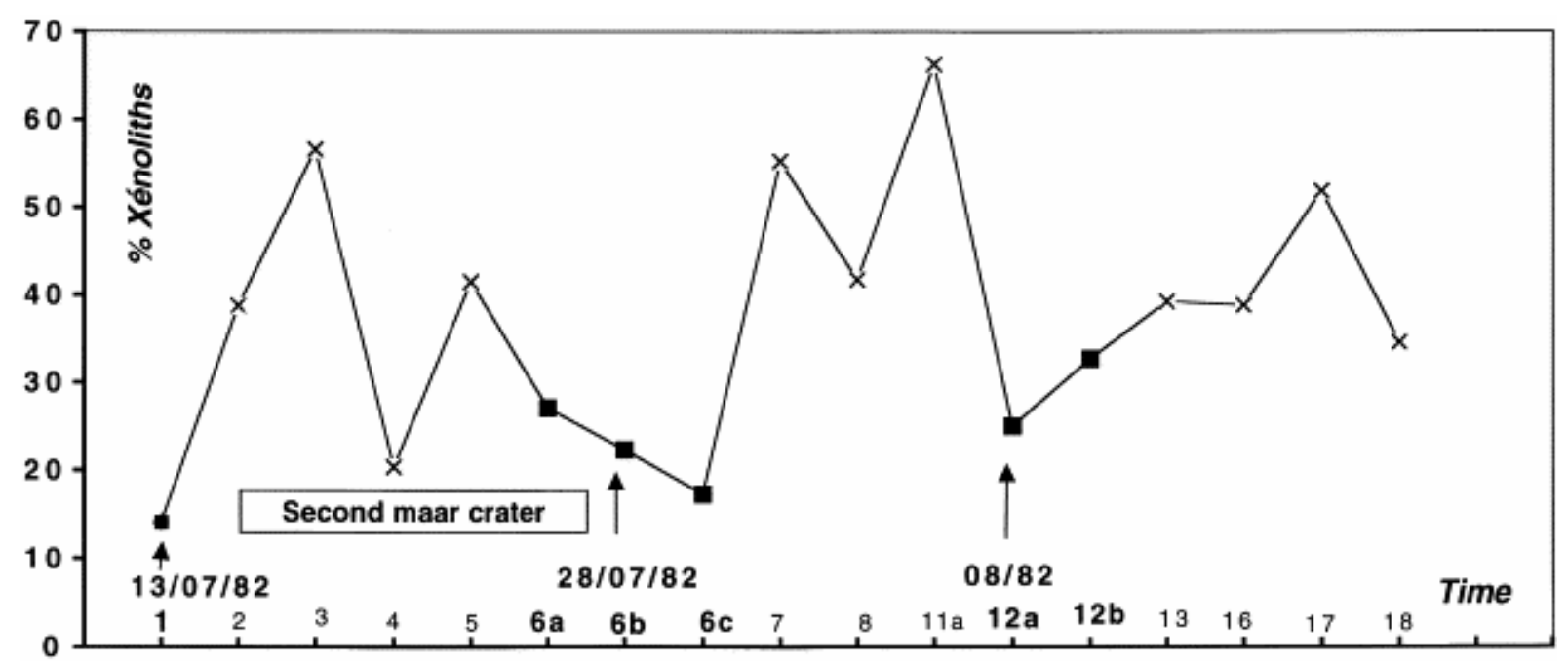

Fig. 6. Variation of the xenolith content in the size class $2.8-4 \mathrm{~mm}$ through time in pyroclastic deposits (flow deposit: black square, surge and fall deposit: cross) of the Hot River area. Numbers 1-18 stand for sample sites (section 1 in Fig. 3) in stratigraphic order. 

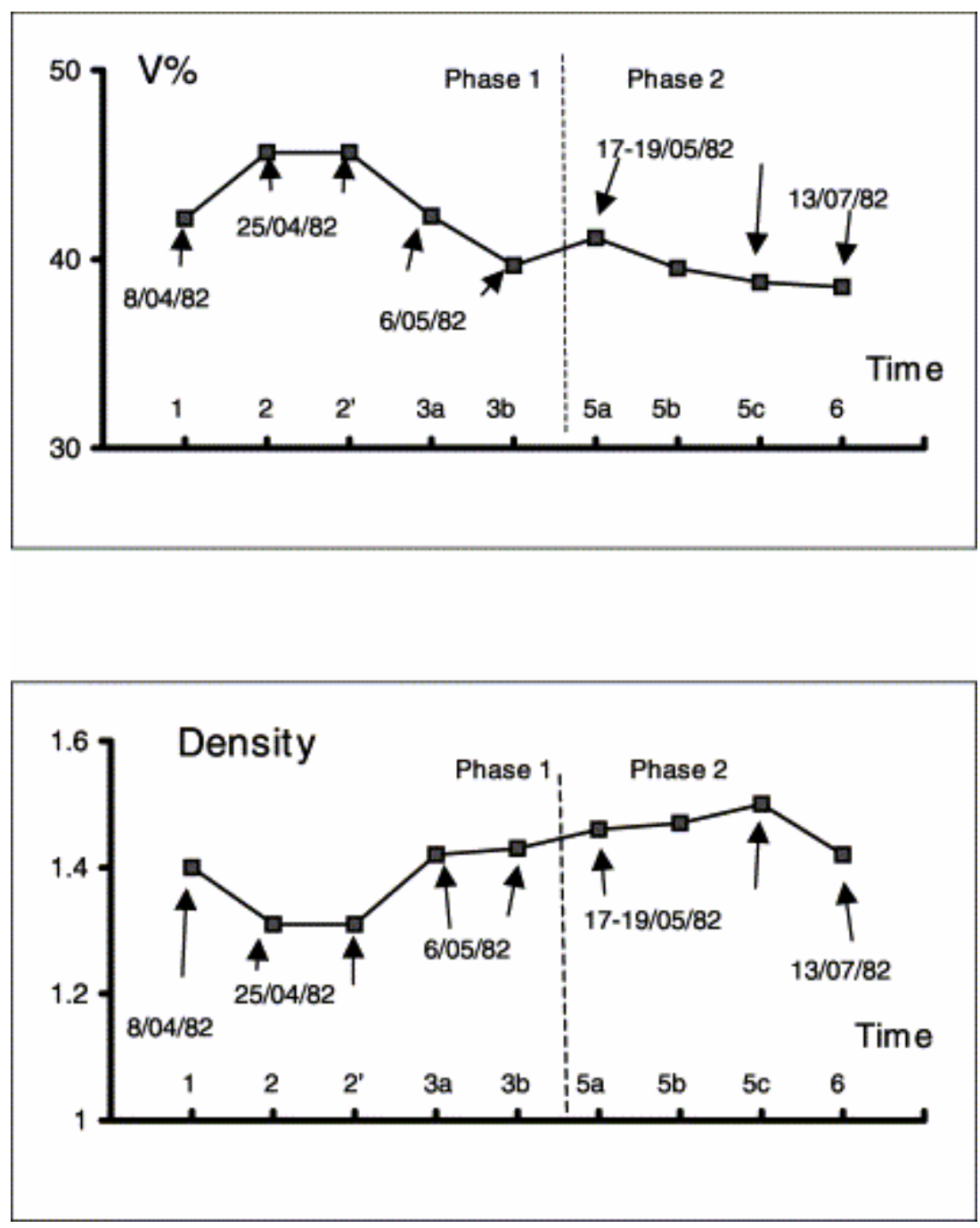

Fig. 7. Evolution of the vesicularity index $(V \%)$ and density of vesiculated clasts through time in pyroclastic-flow deposits from the Cibanjaran valley. Numbers 1-6 stand for sample sites (sections 4 of Fig. 3) in stratigraphic order. 


\section{Table}

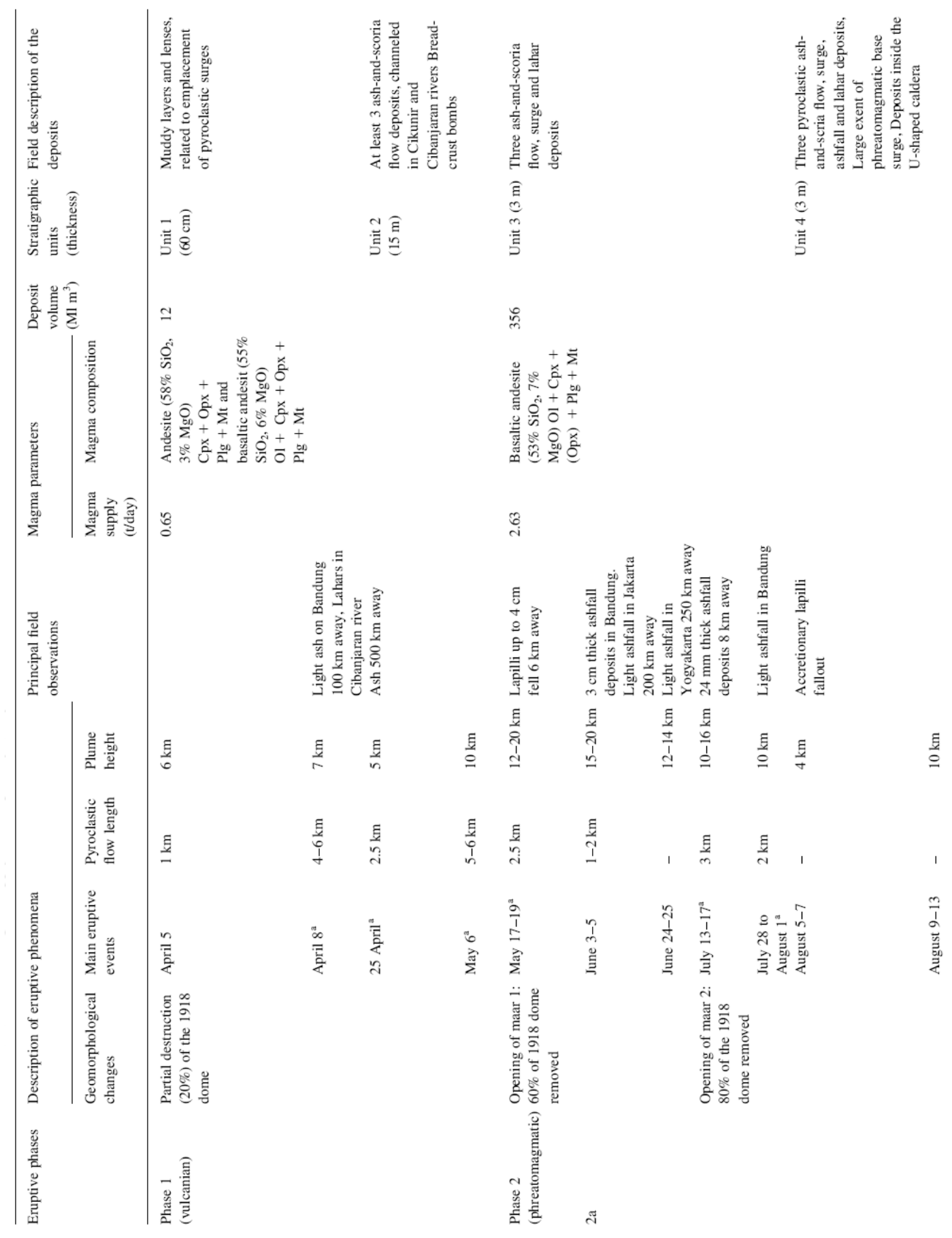




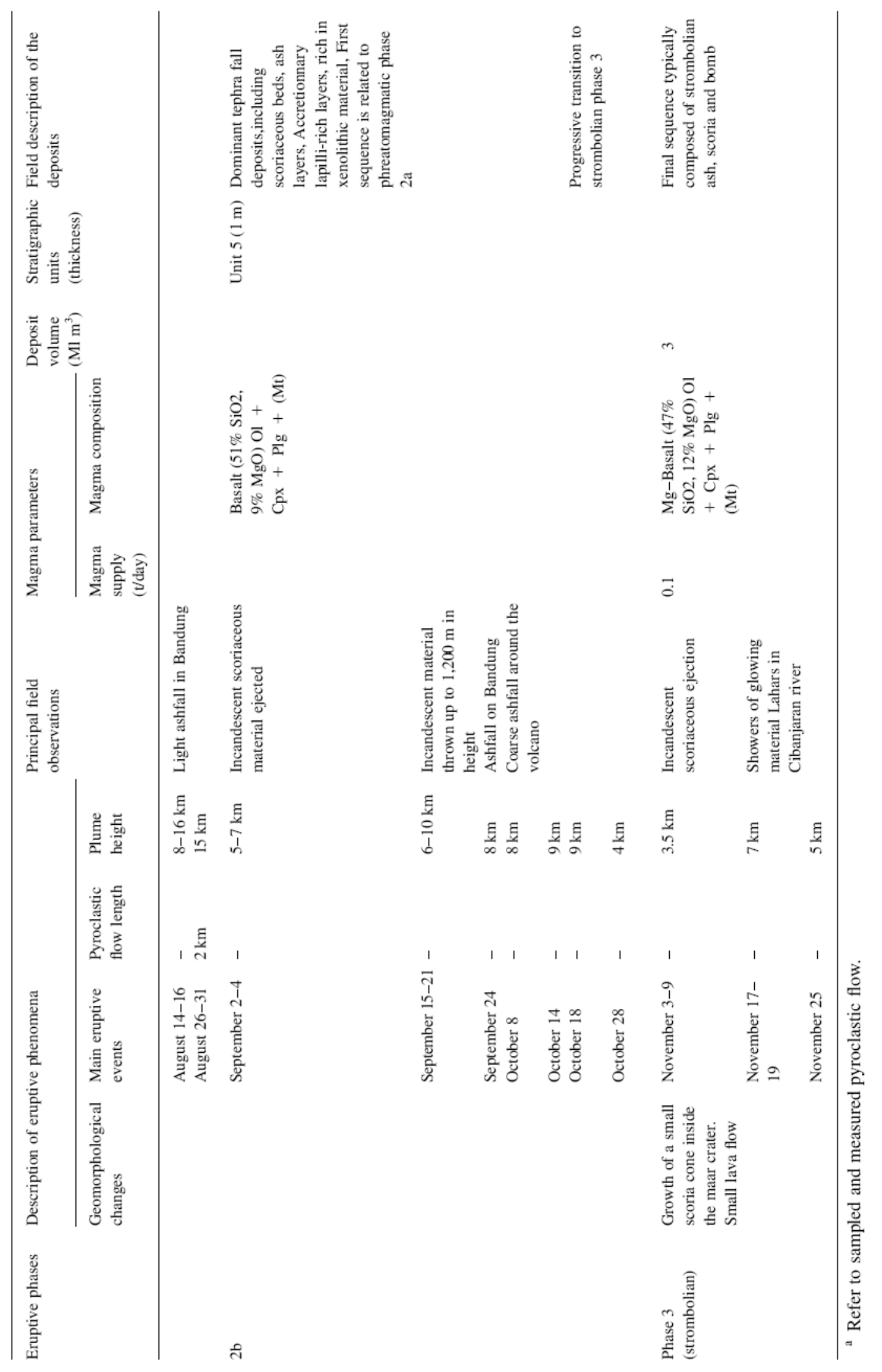

